\title{
Letter to the editor: Sequencing bias for residue 28 of the neuraminidase of the recent highly pathogenic avian influenza virus $\mathrm{A}(\mathrm{H} 5 \mathrm{~N} 8)$
}

Jinyue Guo ${ }^{1}$, Congying Wang ${ }^{1}$, Shujian Huang ${ }^{1}$, Feng Wen ${ }^{1}$

1. College of Life Science and Engineering, Foshan University, Foshan, Guangdong, China

Correspondence: Feng Wen (wenf@fosu.edu.cn)

Citation style for this article:

Guo Jinyue, Wang Congying, Huang Shujian, Wen Feng. Letter to the editor: Sequencing bias for residue 28 of the neuraminidase of the recent highly pathogenic avian influenza virus A(H5N8). Euro Surveill. 2021;26(36):pii=2100829. https://doi.org/10.2807/1560-7917.ES.2021.26.36.2100829

To the editor: We read with great interest the recent rapid communication by Pyankova et al. entitled 'Isolation of clade 2.3.4.4b $\mathrm{A}\left(\mathrm{H}_{5} \mathrm{~N} 8\right)$, a highly pathogenic avian influenza virus, from a worker during an outbreak on a poultry farm, Russia, December 2020' [1]. This report described the genetic characterisation of the first human case of a highly pathogenic avian influenza virus (HPAIV) $\mathrm{A}\left(\mathrm{H}_{5} \mathrm{~N} 8\right)$ isolated from a poultry worker in Russia. We would like to share our perspective on the polymorphism of residue 28 of the neuraminidase of influenza $\mathrm{A}\left(\mathrm{H}_{5} \mathrm{~N} 8\right)$ viruses.

The re-emergence of HPAIV of subtype $\mathrm{A}\left(\mathrm{H}_{5} \mathrm{~N} 8\right)$ globally is a concern for both the poultry industry and public health [2]. In December 2020, Pyankova et al. collected nasopharyngeal swabs from 37 poultry farm workers during an outbreak of $\mathrm{A}\left(\mathrm{H}_{5} \mathrm{~N} 8\right)$ HPAIV in the Astrakhan region in southern Russia. Their whole genome sequencing results suggested that the human isolate, passaged on MDCK cells, had an amino acid substitution $\mathrm{S} 28 \mathrm{~N}$ in the neuraminidase (NA) protein, while all clinical samples had the $28 \mathrm{~S}$ amino acid. As the authors themselves write "The absence of $28 \mathrm{~N}$ in $N A$ sequences of clinical specimens could be due to bias that may have been introduced by using nested PCR". However, we would like to point out that the absence of $28 \mathrm{~N}$ in NA sequences is not likely to be a sequencing bias by nested PCR.

Since November 2020, our diagnostic laboratory has performed surveillance for avian influenza virus in domestic geese in Guangdong, China. RNA was extracted directly from clinical samples with Body Fluid Viral DNA/RNA Miniprep kit (Axygen, Hangzhou, China) and the reverse transcription was performed with a Uni-12 primer. A total of 10 influenza $A\left(\mathrm{H}_{5} \mathrm{~N} 8\right)$ viruses were detected and the NA genes were obtained with a set of universal primers described by Hoffmann et al. [3]. Genes were subcloned into the $\mathrm{pMD}-18 \mathrm{~T}$ vector and sequenced by Sanger sequencing. Sequencing results were deposited at GenBank with accession numbers MZ882169-MZ882176 (haemagglutinin (HA)) and MZ882177-MZ882184 (NA). Our newly identified influenza $A\left(\mathrm{H}_{5} \mathrm{~N} 8\right)$ strains from geese shared high nucleic acid homology with the A/Astrakhan/3212/2020 strain (99-99.8\% for NA, 98.9-99.7\% for $H A)$. Of note, all 10 influenza $\mathrm{A}\left(\mathrm{H}_{5} \mathrm{~N} 8\right)$ isolates had $28 \mathrm{~S}$ in NA. Furthermore, a sequence comparison of the NA gene revealed that residue 28 had a low diversity with an entropy of 0.042 . The substitution $\mathrm{S} 28 \mathrm{~N}$ was found in only $0.39 \%(7 / 1,789)$ of the influenza $\mathrm{A}\left(\mathrm{H}_{5} \mathrm{~N} 8\right)$ strains worldwide (GISAID by 28 August 2021). All closely related influenza $\mathrm{A}\left(\mathrm{H}_{5} \mathrm{~N} 8\right)$ viruses of clade 2.3.4.4b reported in GISAID since November 2020 had $28 \mathrm{~S}$ in NA. Pyankova et al. claimed that the human strain (A/Astrakhan/3212/2020) and one (A/chicken/ Astrakhan/321-06/2020) of five avian strains had $28 \mathrm{~N}$ in NA, however, no original sequence was available for these two isolates.

Notwithstanding, we fully agree that the amino acid substitution $\mathrm{S} 28 \mathrm{~N}$ occurs only rarely and sporadically. We propose that the absence of $28 \mathrm{~N}$ in NA sequences of clinical specimens is normal and is not likely to be a sequencing bias by nested PCR. The presence of $28 \mathrm{~N}$ in the human isolate could be a result of cell adaptation during the passaging of the virus in MDCK cells.

Acknowledgements

We gratefully acknowledge the researchers who submit the HPAIV of subtype $\mathrm{A}\left(\mathrm{H}_{5} \mathrm{~N} 8\right)$ genome sequences in GISAID's EpiFlu Database (www.gisaid.org).

Conflict of interest

None declared. 


\section{Authors' contributions}

FW conceived and designed the manuscript. JG, CW, and SH contributed to the data analysis. FW, JG, CW, and SH commented, revised the manuscript. JG and CW contributed equally to this manuscript. All authors approved the final version of the manuscript.

\section{References}

1. Pyankova OG, Susloparov IM, Moiseeva AA, Kolosova NP, Onkhonova GS, Danilenko AV, et al. Isolation of clade 2.3.4.4b A( $\left.\mathrm{H}_{5} \mathrm{~N} 8\right)$, a highly pathogenic avian influenza virus, from a worker during an outbreak on a poultry farm, Russia, December 2020. Euro Surveill. 2021;26(24):2100439. https:// doi.org/10.2807/1560-7917.ES.2021.26.24.2100439 PMID: 34142650

2. Shi W, Gao GF. Emerging $\mathrm{H}_{5} \mathrm{~N} 8$ avian influenza viruses. Science. 2021;372(6544):784-6. https://doi.org/10.1126/ science.abg6302 PMID: 34016764

3. Hoffmann E, Stech J, Guan Y, Webster RG, Perez DR. Universal primer set for the full-length amplification of all influenza A viruses. Arch Virol. 2001;146(12):2275-89. https://doi. org/10.1007/s007050170002 PMID: 11811679

\section{License, supplementary material and copyright}

This is an open-access article distributed under the terms of the Creative Commons Attribution (CC BY 4.0) Licence. You may share and adapt the material, but must give appropriate credit to the source, provide a link to the licence and indicate if changes were made.

Any supplementary material referenced in the article can be found in the online version.

This article is copyright of the authors or their affiliated institutions, 2021. 